\title{
Participações governamentais:
} atribuição de custos e distribuição de renda - notas de leitura*

\section{Government participation: costs assignment and income distribution - reading notes}

\author{
Gustavo Kaercher Loureiro**
}

\section{RESUMO}

O presente estudo, que toma a forma de uma alongada resenha bibliográfica, discute possíveis balizas para uma distribuição federativa das participações governamentais da indústria do petróleo, tal qual preconizada pelo art. 20, $\S 1^{\circ}$ da Constituição Federal. Para isso, afasta-se de uma discussão abstrata e acolhe a perspectiva econômica calcada na distinção entre "atribuição de custos" e "distribuição de rendas", proposta pelos professores Giorgio Brosio, professor de economia da Universidade de Turim, e Juan Pablo Jimenes, economista da Cepal.

* Artigo recebido em 11 de novembro de 2012 e aprovado em 8 de março de 2013.

** Professor de direito administrativo e constitucional da Universidade de Brasília (UnB). Coordenador do Grupo de Estudos em Direito dos Recursos Naturais (Gern/UnB). Universidade de Brasília, Brasília, Distrito Federal, Brasil. E-mail: gustavo.kaercher@kbadvogados.com. 
PALAVRAS-CHAVE:

Participações governamentais - atribuição de custos - distribuição de renda

\section{ABSTRACT}

This study, which takes the form of an elongated bibliographic review, discusses possible goals for distribution of federal government participation in the oil industry, as is advocated by art. $20, \S 1^{\circ}$ of the Federal Constitution. For this, departs from an abstract discussion and welcomes the causeway economic perspective on the distinction between "cost assignement" and "income distribution", proposed by Professor Giorgio Brosio, Professor of Economics, University of Turin, and Juan Pablo Jimenes, Cepal economist.

\section{KEY-WORDS}

Government participation - costs assignment - income distribution

Em tempos de discussão acirrada e por vezes emocional acerca da repartição das receitas públicas ${ }^{1}$ proporcionadas pela indústria do petróleo, e diante de um texto constitucional de não simples interpretação, é sempre saudável para o jurista ampliar o seu horizonte de reflexão e, sobretudo, procurar ordenar ideias e argumentos que aparecem no debate de forma pouco clara e carentes de melhor contextualização.

Essa falta de clareza aparece, sobretudo, quando se trata de buscar a finalidade da norma cuja interpretação se disputa (nossa bem conhecida "interpretação teleológica"), para tirar daí afirmações pro et contra determinada proposta de partilha.

Diz-se, por exemplo, que o comando inserido no art. 20, $\S 1^{\circ}$ da Constituição ${ }^{2}$ deve ser entendido como determinando a exclusividade (ou, no

1 Emprega-se aqui um termo "neutro" para indicar todo e qualquer ingresso proveniente especificamente da exploração de recursos naturais (petróleo, no que interessa), que não seja fruto da imposição tributária tradicional (Imposto de Circulação de Mercadorias - ICMS, Imposto de Renda de Pessoa Jurídica - IRPJ etc.). Grosso modo, trata-se das participações governamentais do art. 45 da Lei n⿳0 9.478/1997.

2 "Art. 20 - São bens da União: (...); V - os recursos naturais da plataforma continental e da zona econômica exclusiva; (...); IX - os recursos minerais, inclusive os do subsolo; (...). $\S 1^{\circ}-$ É assegurada, nos termos da lei, aos Estados, ao Distrito Federal e aos Municípios, bem 
mínimo, preferência) da destinação dos resultados dessas receitas para as regiões produtoras porque serviriam elas para indenizar estados e municípios pelos "problemas gerados na exploração destes tipos de recursos energéticos e minerais" ${ }^{\prime 3}$.

Por mais intuitivas que possam ser afirmações deste tipo, e mesmo que estejam corretas, elas perdem força argumentativa na medida em que permanecem na superficialidade do problema e não extraem as consequências que delas decorrem.

Quanto à superficialidade: as afetações das regiões "produtoras" são de variadíssimo tipo e não podem ser tratadas de modo homogêneo.

Sem mesmo admitir que tais ocorrências se verificam sempre, há que se distinguir, entre "prejuízo" e "impacto"; entre diferentes tipos de "prejuízos", provenientes de diferentes tipos de "danos"; entre diferentes tipos de "impacto", provenientes de diferentes fatores e características da indústria, técnicos, temporais, econômicos etc.

Fala-se em dano, mas de qual tipo? Ambiental, paisagístico, turístico? E, se ambiental, cuida-se do acidente ambiental, esporádico e identificável, normalmente indenizável in casu, ou daquele chamado residual, pouco perceptível no instante, decorrente da (natural) degradação do ambiente ao longo dos anos, das "manchas órfãs", da queima de gás em flares etc.? Seriam todos tratáveis do mesmo modo?

Ao lado do dano, há o impacto. Há aquele que se verifica no presente e se prolonga por certo tempo, e que consiste em uma demanda crescente por infraestrutura para acomodar as (novas) necessidades da indústria e

como a órgãos da administração direta da União, participação no resultado da exploração de petróleo ou gás natural, de recursos hídricos para fins de geração de energia elétrica e de outros recursos minerais no respectivo território, plataforma continental, mar territorial ou zona econômica exclusiva, ou compensação financeira por essa exploração."

3 SILVA, Sandra Maria do Couto; OLIVEIRA, Jorge Rubem Folena. Dos royalties do petróleo: o Princípio Federativo e a competência dos estados para editarem leis sobre sua cobrança e fiscalização. Disponível em:<www.pge.proderj.rj.gov.br/Revista63/0313-DosRoyaltesPetroleo. pdf $>$. Argumentações genéricas também podem ser encontradas em KERN, Rodrigo Lima. Interpretação do art. 20, $11^{\circ}$, da Constituição Federal - A necessidade de tratamento isonômico entre estados e municípios produtores de petróleo, energia elétrica e recursos minerais. Disponível em: <http://jus.uol.com.br/revista/texto/14639/interpretacao-do-artigo-20-1o-daconstituicao-federal>, que fala numa "indenização pela utilização do território" (p. 5); em PIRES, Adilson Rodrigues. Breve ensaio sobre as participações governamentais nas atividades de exploração e extração de petróleo. In: Aspectos tributários relacionados à indústria do petróleo e gás. Rio de Janeiro: MP Editora, 2011. O autor entende que "[A] remuneração prevista no texto da Carta Magna não constitui espécie tributária, mas sim compensação pelo comprometimento do solo brasileiro, em face do efeito predatório da exploração" (p. 93). 
da população que ela atrai (estradas, escolas, hospitais, segurança pública, urbanismo etc.). Essas exigências têm um limite ou uma curva de intensidade? De outro tipo é o impacto "intergeracional" eis que os fatores produtivos de uma região hospedeira tendem a orbitar em torno do empreendimento petrolífero que tem duração limitada. Finda a exploração, no futuro, o que se pode fazer para que a região não se torne uma imensa cidade fantasma ou para que as futuras gerações que ali nascem não fiquem presas a uma terra economicamente estéril? Alguém deve financiar, em paralelo à exploração de recursos naturais, investimentos em padrões de desenvolvimento alternativos? Quem?

A falta de distinções apropriadas vem acompanhada da (consequente) falta de tratamento adequado e específico de cada circunstância.

No debate jurídico por vezes se esquece também de outro elemento de grande importância: esses fenômenos apontados como razões da norma são empiricamente verificáveis e, no mais das vezes, mensuráveis com relativa acurácia.

Daí a questão natural: se o fundamento da norma constitucional é esse (ou são esses), e se se deve levar a sério tal fundamento e extrair dele tudo o que oferece, então a participação dos entes subnacionais está condicionada por tais perdas e deve ser calculada em função delas? Já foi dito pelo Supremo Tribunal Federal no leading case RE 228.800, que se a CFEM (a receita setorial proveniente da mineração) for uma verdadeira compensação financeira, então ela "há de ser entendida em seu sentido vulgar de mecanismo destinado a recompor uma perda, sendo, pois, essa perda o pressuposto e a medida da obrigação do explorador".

Assumir que tais afetações (dano ou impacto) sejam o (único) fundamento da distribuição constitucional certamente leva a uma partilha diferenciada em favor dos chamados "produtores", mas por outro lado - e disso pouco se apercebem os defensores da tese - limita a receita a que têm direito: a perda passa a ser "o pressuposto e a medida" da receita do ente público. Daí que duas ulteriores ilações poderiam ser feitas, nenhuma delas benéfica aos "produtores": ou bem a receita pública fica limitada a isso ou bem todo e qualquer excesso pode ser livremente distribuído em favor dos demais agentes públicos. Ou seja, o argumento poderia ser um verdadeiro "tiro no pé".

Em todo caso, não se quer, aqui, tomar posição acerca do debate, mas propor uma sua mais consistente apresentação e condução.

E, nesse ponto, afigura-se de muita utilidade um recente estudo realizado por Giorgio Brosio, professor de economia da Universidade de Turim, em coautoria com Juan Pablo Jimenez, economista da Cepal, intitulado 
"The intergovernmental assignment of revenue from natural ressources: a difficult balance between centrifugal and centripetal pressures". ${ }^{4}$

O estudo compõe-se de duas partes, uma analítica, dedicada à clarificação conceitual; outra comparativa, em que são apresentadas diversas experiências de repartição das receitas na América Latina.

Interessa aqui, especialmente, a primeira parte.

Seguindo na trilha de estudo anterior de Brosio, ${ }^{5}$ a preocupação dos autores, situada no grande tema da repartição federativa das receitas públicas da indústria do petróleo, é tríplice: ${ }^{6}$

(i.) identificar exatamente o objeto da repartição;

(ii.) avaliar a cogência dos argumentos econômicos contra a repartição federativa das receitas;

(iii.) apresentar algumas alternativas distributivas e estabelecer (poucas) recomendações acerca dessa repartição.

Quanto ao primeiro ponto, de maior interesse para o debate ora em curso no Brasil, os autores lançam observações e distinções que muito utilmente poderiam ser incorporadas ao debate dos juristas que tratam desse problema.

A distinção básica aqui operada é entre imputação de custos e distribuição de renda. E a tese afirmada é tão clara quanto esclarecedora: uma verdadeira "questão federativa" apenas surge quando todos os custos gerados pela indústria ${ }^{7}$ forem devidamente reconhecidos, computados e internalizados pelos agentes produtores que devem satisfazer os dispêndios dos agentes públicos hospedeiros ou de algum modo verificável pelos diretamente afetados. Apenas o que sobrar depois dessa apropriação será a verdadeira renda, ${ }^{8}$

4 Disponível em: <www.eclac.cl/ilpes/noticias/paginas/1/41751/Brosio_Jimenez_Fiscal_policy_ seminar.pdf>.

5 BROSIO, Giorgio. Oil revenue and fiscal federalism. In: DAVIS, Ossowski Fedelino (Org.). Fiscal policy formulation and implementation in oil-producing countries. Washington: FMI, 2003. p. 243-269. Esse texto será usado aqui como pano de fundo e complemento, para dar ao leitor brasileiro uma mais ampla perspectiva dos estudos conduzidos pelo professor Brosio.

6 Esta resenha não segue rigorosamente a ordem de exposição do texto, mas, antes, apresenta um iter que, na visão de quem escreve, melhor serve aos propósitos da discussão brasileira.

7 "Costs consist of remunerations to all production factors needed for the production. They include typically labour, material and non material inputs and capital. The cost of capital includes also a premium for risk that in the case of mining and oil production can be substantially high, due to the uncertainties about the effective size of mines and oil fields, about trends in costs and, most of all, about fluctuations in the price of the commodities." (Brosio e Jimenez, The intergovernmental assignment of revenue from natural resources, op. cit., p. 11).

8 "Rent is the return to a resource whose total supply is fixed and it is measured as the difference between the revenue derived from the sale of the resource and all the economic costs needed for its production. When total costs do not add up to the value of the production, a rent is generated. Rent is in fact a surplus value." (Ibid., p. 11; grifos acrescentados) 
cujo destino deve passar pelo exame da conveniência/inconveniência da distribuição federativa e suscitar questões ulteriores, relativas ao melhor modo de alocação.

Só o reconhecimento desta distinção analítica já seria de grande valia para o debate jurídico que se instalou no Brasil. Mas há mais.

Em particular, dois custos identificados por Brosio e Jimenez costumam ser incorporados pela literatura jurídica nacional na questão diversa, da distribuição da renda: (i.) os investimentos estatais (de qualquer esfera da Federação) em infraestrutura necessária para absorver a instalação da indústria; ${ }^{9}$ (ii.) certos custos ambientais.

Quanto aos primeiros, afirmam os autores:

If government provided services contribute effectively to the production, they have to be considered as additional production factors, or as inputs. Examples are roads and communications, school and health services to the persons employed in the oil fields and mines, and their families. In other words, all services that oil firms would have to provide (also through higher wages) if governments did not act have to be considered. Their cost has to be subtracted from the final price. Governments are entitled to a share of the final price of oil not because they have a sovereign right to the rent, but because they are partners in the production (...).

The conclusion is that also in this case the cost of infrastructure for providing services to the population that has migrated to a oil field or mine area does not form part of the rent, has to be added to other costs and has to be funded to the level government that has actually provided the services and borne the costs. The relative importance of the costs refunded to the central or to the regional government will depend on the extent of responsibilities assigned to them. ${ }^{10}$

9 Segundo os autores, tais custos, embora complexos, podem ser identificados e quantificados com relativa precisão: "In principle, payments to them could be calculated very precisely on the basis of the value of these services. This would also determine the individual shares of the central and the regional governments" (Ibid., p. 11).

10 Ibid. No estudo anterior de Giorgio Brosio, o mesmo ponto é apresentado em termos mais amplos: "Although most investment for the exploitation of oil and other national resources is made directly by the producing companies, additional investment in local infrastructure is usually needed. Roads to the producing fields have to be built; airports and ports may have to be upgraded; school, health, and social services have to be expanded to serve the growing population attracted to the area. If the demand for these services exceeds the level that would have prevailed in the absence of oil and natural resources extraction, the governments of the producing jurisdictions are entitled to have these additional costs funded. Since the oil rent is the income in excess of that required to cover the costs of all 
O segundo elemento envolve o inegável impacto ambiental da indústria.

É importante que se esclareça - e aqui vai outra distinção por vezes perdida - que por "impacto ambiental" os autores não parecem entender o dano ambiental pontual (o "acidente ambiental"), identificável como um evento a se e quantificável in casu. Trata-se de incorporar, como custo de produção, a indesejável mas inevitável degradação paulatina do meio ambiente, que se processa como resultado normal da instalação da indústria. Embora os autores não afirmem tal, é de se supor que, em caso de ocorrência de dano específico e anormal, o tratamento que dariam é o de seguir as exigências da responsabilidade ambiental da legislação setorial. ${ }^{11}$

Sem adentrar na sofisticada apresentação do problema feita pelos autores, deve-se reconhecer, em primeiro lugar, que tal impacto é primariamente (mas não exclusivamente) local e, em segundo lugar, que tal impacto deve ser objeto de neutralização ou de compensação, circunstância que retira esse item de cogitações acerca de uma partilha de rendas petrolíferas. Ele é um elemento de custo a ser suportado pelo agente econômico causador do impacto.

Quanto ao destinatário dessa compensação, os autores figuram duas hipóteses: ou bem tais custos já são internalizados por meio de definições jurídicas relativas a standards de conduta ("de poluição") e de imposições de "taxas ambientais" e o problema está resolvido; ${ }^{12}$ ou bem tal não ocorre e o problema relativo ao modo de apropriação e destinação se complica. ${ }^{13}$ Para lidar com tal segunda situação, formulam hipóteses que correlacionam responsabilidade

inputs necessary for production, both efficiency and equity considerations suggest that the costs faced by subnational governments are refunded before this rent is distributed. In other words, only the net rent has to be allocated" (Brosio, Oil revenue and fiscal federalism, op. cit., p. 252).

11 Em nosso direito vige o princípio da responsabilidade civil objetiva e o dever de reparação integral, nos termos do art. 14, §2o da Lei $\mathrm{n}^{\circ}$ 6.938/1981.

12 "We have to distinguish between two polar cases and see their implications concerning the rent. In first case, which is the situation that should prevail, at least in principle, the property rights are perfectly defined and exploiting firms have to comply with government policies. The government (whose level has still to be defined) sets the standards (regulatory approach) or determines and levies the environmental tax (or, more unlikely, determines and pays a subsidy to the natural resources exploiting companies). In this case, if the companies comply with the standards or pay the tax, they will have an additional cost to be added to the previous ones and to be recognized to them. The use of the environment just becomes another production factor and another cost for the firms" (Brosio e Jimenez, The intergovernmental assignment of revenue from natural resources, op. cit., p. 12).

13 "In the second case, the property rights are not defined and the standards are not issued or not enforced. The firm's uses, or better spoils, the environment and the cost will be borne by the society at large. (...) In this case the society has to be refunded of the cost it has to bear because of the environmental damages and compensation, which is paid out of the rent, will correspond to the expenditure that would have been necessary to comply with the standards, or, alternatively, to the foregone tax revenue. But who is entitled to this compensation?" (Ibid.). 
regulatória/fiscalizatória e titularidade dos recursos recebidos a título de compensação ambiental. ${ }^{14}$

Como quer que se resolva este segundo problema, certo é que, quanto a estes dois elementos, não se põe propriamente uma "pergunta federativa": os entes afetados empiricamente pela instalação da indústria estão habilitados a obter um ressarcimento do que podem ser investimentos feitos ou prejuízos sofridos.

Apenas depois de identificados, separados e devidamente computados esses elementos de custo (com a alocação aos sujeitos que os suportam) é que se colocaria a questão "verdadeira", i.e., relativa à distribuição da renda, se existente:

It is possible, but unlikely under the prevailing circumstances, that the sum of these costs is big enough to absorb all the value of the production and that no rent is created. The most likely case is that the absorption of value by costs is not complete, leaving a rent to appropriate. In both cases the use or the factor theory allows to make some considerable progress in the issue of the allocation of the rent by clarifying the entitlements of governments. More precisely, it makes a clear case, based on sound economic theory, for paying part of the value of the production to governments for the services they provide and not on the basis of a sovereign right to the rent. ${ }^{15}$

Aqui, na verdade, é que deveria começar nosso atual debate.

14 Ibid., p. 13-14.

15 "The intergovernmental assignment of revenue from natural ressources (...)". Ibid., p. 14. Esta renda compõe-se, segundo Brosio e Jimenez, de dois elementos, a chamada renda diferencial e outra parcela, qualificada como other rents. A primeira corresponde, aparentemente, à renda clássica ou ricardiana. Trata-se de um excedente que surge em favor de certas explorações minerais mais "produtivas" se comparadas com outras, qualificadas como "marginais". Como o preço de mercado do insumo é determinado pelos custos de produção da jazida marginal (o preço marginal determina os preços de todo o mercado), e estes são mais altos do que os das melhores jazidas, verifica-se em favor destas um ganho adicional, dito diferencial em razão, exatamente, da diferença de produtividade (decorrente de qualquer fator, natural ou não, para evitar entrar numa ulterior discussão que envolve os conceitos de "renda" e "quase renda"). A segunda decorre, sobretudo, de flutuações no preço do recurso natural. Alguns autores identificam, ainda, outras rendas apropriáveis; ver POSTALI, Fernando Antônio Slaibe. Renda mineral, divisão de riscos e benefícios governamentais na exploração de petróleo no Brasil. Rio de Janeiro: BNDES, 2002; SERRA, Rodrigo Valente. Contribuições para o debate acerca da repartição dos royalties petrolíferos no Brasil. Tese (doutorado). Disponível em: <www.royaltiesdopetroleo. ucam-campos.br/index.php?cod=4>. Como quer que seja, este é o surplus econômico que está em jogo na distribuição de renda (Brosio e Jimenez, The intergovernmental assignment of revenue from natural resources, op. cit., p. 14-15). 
Dele é que se ocupam os pontos (ii.) e (iii.), acima indicados, ${ }^{16}$ que giram em torno de argumentos de tipo econômico pro et contra a descentralização das rendas.

A bem guardar, e tendo presente o art. 20, §1ํㅡ, da Constituição, essas são questões cuja dramaticidade é mitigada no Brasil, eis que o legislador constitucional já determinou, em termos genéricos, que a receita advinda da exploração de um bem público federal (art. 20, §1o e art. 176) deverá ser descentralizada entre estados e municípios (e ainda "órgãos da Administração Direta da União").

Em todo caso, mesmo diante dessa decisão de nosso direito positivo constitucional, os problemas suscitados por Brosio e Jimenez em torno dos méritos da distribuição interessam ao nosso ordenamento jurídico na medida em que esse mesmo texto deixa grande margem de manobra em favor do legislador [nacional] infraconstitucional (ordinário) para (i) a identificação precisa dos estados/municípios a serem beneficiados quando a exploração se der na plataforma continental; ${ }^{17}$ (ii) o estabelecimento de percentuais da distribuição entre os legitimados e (iii) a fixação do destino a ser dado à receita.

Se assim é, uma eventual conclusão negativa quanto à conveniência de uma distribuição pode ser tomada entre nós como uma recomendação ao legislador para que estabeleça uma menos generosa porção, note-se bem, $d a$ renda (e não dos ressarcimentos de custos incorridos pelos estados/municípios, conforme supra) para os entes regionais e locais.

Além dessa circunstância, algumas reflexões dos autores acerca das formas alternativas de realizar a distribuição - antecipa-se que entendem eles ser recomendável/inevitável uma descentralização de receitas - são, em qualquer caso, de muita utilidade para o estudioso brasileiro.

16 Como se disse, a ordem de exposição do artigo não foi respeitada nesta resenha.

17 Aqui convém um esclarecimento hermenêutico: ao contrário do que sustenta a maioria dos defensores da partilha diferenciada, entendo que o texto constitucional, do ponto de vista estritamente gramatical, é, sim, ambíguo (em sentido contrário, por todos, BARROSO, Luis Roberto. Federalismo, isonomia e segurança jurídica: inconstitucionalidade das alterações na distribuição de royalties do petróleo. Parecer elaborado para o estado do Rio de Janeiro em 16/6/2010. Disponível em: <www.migalhas.com.br/arquivo_artigo/art20100708-01.pdf>). Isso se afirma na medida em que, em termos semânticos, o "respectivo" do texto tanto pode reger apenas o "território" quanto o resto todo, ou seja, a "plataforma continental, mar territorial e zona econômica exclusiva". É justamente esta ambiguidade que permite a formulação (não a justificação, bem entendido) das Emendas Ibsen-Simon e outras, que propugnam uma partilha igualitária das receitas. Para afastar essa ambiguidade são necessários outros instrumentos interpretativos que, em meu entender, levam à conclusão de que o texto constitucional pretendeu estabelecer um critério diretamente "geográfico" de distribuição. Em todo caso, não é hora de tratar deste assunto. 
O primeiro argumento tomado por Brosio e Jimenez não é específico do tipo de receita e/ou de sua proveniência (exploração de recursos naturais). Ele se deixa formular sempre que, por qualquer motivo, verifica-se uma diferença relevante entre os ingressos públicos a que têm direito diferentes regiões de um mesmo país. Admitida essa circunstância que desequilibra em favor de certa área a base fiscal, a tese enuncia o que se poderia qualificar como uma tendência (que tem pretensão de ser empiricamente constatável): a região mais favorecida tenderá a adotar uma política de gastos públicos - notadamente de atração de atividades - que distorcerá a dinâmica econômica geral, causando ineficiência de alocação de trabalho e investimentos produtivos privados.

A partir de pesquisas anteriores, Brosio e Jimenez analisam o que seria uma possível consequência dessa política ineficiente, a migração de trabalho das regiões menos aquinhoadas com recursos públicos para aquelas mais ricas; concluem, em síntese, que (i) a tendência apontada carece de melhor verificação empírica e está sujeita, em ocorrência e magnitude, a inúmeras variáveis; (ii) mesmo que fosse procedente na maior parte dos casos, dificilmente se verificaria na América Latina, considerando que as regiões favorecidas com a distribuição oferecem, em troca, dificuldades adicionais de instalação capazes de neutralizar a potencial vantagem/distorção. ${ }^{18}$

O segundo argumento diz respeito a uma característica específica do mercado de recursos naturais que tem impacto direto no fluxo de receitas públicas a eles ligado: a instabilidade de preços desses produtos provoca uma grande volatilidade dos montantes arrecadados ao longo do tempo, destinados aos entes públicos.

Esse traço - admitido - não recomendaria a descentralização das receitas porque se considera o ente público central mais capaz de compensar essas oscilações de ingressos - dada a maior área de manobra fiscal que possui - evitando as consequências negativas tanto de um superafluxo quanto de escassez:

18 "The magnitude of the loss depends on migration elasticities, which depend, on region specific factors. For example, migration elasticities in Alaska are surely much lower than in the other American states, and also in Canada they seem to be quite low, according to recent studies.// The relevance of factors mobility argument should be even lower for Latin American countries, where most natural resources are local in very remote, and sometimes, even inhospitable areas" (Brosio e Jimenez, The intergovernmental assignment of revenue from natural resources, op. cit., p. 10). De notar-se, porém, que no caso de exploração de petróleo na plataforma continental, as áreas não são de difícil acesso nem oferecem particulares dificuldades ou barreiras que dificultem a migração dos fatores de produção. 
The first and one of the strongest arguments against assignment of natural resources revenue to subnational governments is volatility. The reason is that the central government is better equipped than its subnational units to face revenue fluctuations, considering its access to a wider range of financial instruments. When revenue diminishes abruptly, subnational units have to resort to expenditure cuts, thus endangering even the provision of minimum levels of essential services, such as education and health, where these are decentralized. During upturns in prices, subnational jurisdictions would be literally awash of money they are unable to spend efficiently, or have to enter into spending commitments that might not be sustainable in the longer term. Another, somewhat more elaborated, way of arguing about volatility is that price fluctuations make non renewable resource rents a non "reliable" sources of revenue. The consequence is that funding "reliable" expenditure, such as salaries and other current expenditures, with volatile revenues carries higher risk for which LGs are not equipped, implying higher cost. ${ }^{19}$

A posição, em síntese, dos autores é, novamente, de prudência quanto à efetividade dessa (novamente) tendência, formulada em termos demasiado genéricos:

However, the argument looses much of its strength when rent is used for investment, or debt redemption. Reliability would not matter in these cases. Hence, and de facto, the argument depends on the size of rent, and on its regional distribution: a small region cannot spend huge rent only for investment, but a large region may be able. More in general, large regions could, in principle, solve the risk problem, as well as the central government. ${ }^{20}$

É interessante notar, de passagem, que o direito brasileiro sempre manifestou, em maior ou menor intensidade, preocupação com o destino das receitas advindas da exploração de recursos naturais e, mais particularmente, do petróleo, ${ }^{21}$ muito embora, recentemente, essa vinculação tenha se

Ibid., p. 15-16.

Ibid., p. 16.

21 Sobre este ponto, em geral, TORRONTEGUY, Alessandra Fölzke. A aplicação dos royalties do petróleo na efetividade dos direitos fundamentais sociais. São Paulo: LTr, 2011. Atualmente, a situação parece ser a seguinte, especificamente para a parcela de royalties até 5\%: "Art. 8ㅇ $\mathrm{O}$ pagamento das compensações financeiras previstas nesta Lei (...) será efetuado, mensalmente, diretamente aos Estados, ao Distrito Federal, aos Municípios e aos órgãos da Administração 
afrouxado, com os critérios trazidos pela Lei no 9.478/1997. A explicação para tal vinculação pode estar aí.

Por fim, o derradeiro argumento por eles analisado diz respeito ao possível risco de "maus gastos" (misspendigs), a que estariam especialmente submetidas unidades políticas de menor dimensão (econômica e territorial), em virtude da afluência excessiva de recursos com os quais não conseguiriam lidar adequadamente. De modo mais específico, esta desproporção poderia ensejar inversões públicas não economicamente eficientes (perdulárias), declínio de fiscalização do controle dos gastos (complacência administrativa) e mesmo pura e simples facilitação para barganhas políticas desprovidas de racionalidade (ou mesmo economicamente danosas) ou, no limite, corrupção. ${ }^{22}$

Mais uma vez, a réplica de Brosio e Jimenez reconhece a pertinência das observações, que toma como advertências, mas não como fatores capazes de determinar peremptoriamente a política de concentração de recursos.

Em síntese, e para todas as objeções, "While surely important, these arguments are not general enough to make a strong; decisive point against assignment to subnational levels, especially when the latter are large in terms of population and have capacity". ${ }^{23}$

Há, pois, espaço, na visão dos autores, para implementar políticas de distribuição da renda petrolífera.

A questão a que se dedicam a seguir é indicar como fazer isso de modo mais eficiente (e levando em consideração as advertências formuladas pelos defensores da centralização).

Para começar a respondê-la, Brosio e Jimenez assumem duas premissas, quais sejam:

(a) a ocorrência aleatória e espacialmente concentrada de riquezas minerais; ${ }^{24}$

Direta da União (...) vedada a aplicação dos recursos em pagamento de dívida e no quadro permanente de pessoal. (Redação dada pela Lei $n$ o 8.001, de 13.3.1990). §1ํㅡ - Não se aplica a vedação constante do caput no pagamento de dívidas para com a União e suas entidades. (Parágrafo incluído pela Lei $\mathrm{n}^{\circ}$ 10.195, de 14.2.2001) §2º - Os recursos originários das compensações financeiras a que se refere este artigo poderão ser utilizados também para capitalização de fundos de previdência" (Parágrafo incluído pela Lei no 10.195, de 14.2.2001).

22 Brosio e Jimenez, The intergovernmental assignment of revenue from natural resources, op. cit., $\mathrm{p}$. 16-17.

23 Ibid., p. 15.

24 No estudo anterior - e para outros propósitos -, Brosio elencou quatro fatores empíricos que deveriam ser levados em conta para uma correta apreciação da distribuição federativa das receitas: (a.) a concentração territorial das jazidas; (b.) o caráter temporário da exploração; (c.) a volatilidade dos preços dos produtos minerais; (d.) o caráter nacional da política energética 
(b) a necessidade política de repartir, em alguma medida, o surplus econômico (a verdadeira renda petrolífera) entre todo o território nacional. A determinação precisa dessa medida decorreria do resultado da dinâmica de forças de duas tendências políticas de sinais contrários: uma, das regiões produtoras, que aponta para a exclusividade ou, ao menos, preponderância na apropriação das rendas; outra, do resto do país, que aponta para a total isonomia distributiva.

Nesta última etapa (da primeira parte do estudo), os autores não chegam a ponto de preconizar determinada medida de participação - pois isso depende de inúmeros fatores não controláveis e sequer enunciáveis em um estudo teórico - nem, parece, uma mais modesta diretriz relativamente à intensidade da equalização (adiante).

Limitam-se a sugerir um arranjo de competências que melhor realizaria o resultado do embate de forças políticas, qualquer que seja ele (dentro da diretriz geral de realizar, no mínimo, alguma equalização): tratar-se-ia de concentrar a competência arrecadatória no ente central e de criar mecanismos financeiros (centrais) de distribuição, os chamados fundos de equalização. ${ }^{25}$

Tais fundos poderiam ser gerais ou setoriais.

No primeiro caso, os ingressos provenientes da exploração de recursos naturais integram um mecanismo compensatório mais amplo, que pode funcionar de diferentes modos ("horizontal" ou "verticalmente"). ${ }^{26}$ A hipótese,

(Brosio, Oil revenue and fiscal federalism, op. cit., p. 249-251). Essas diferentes características servem como variáveis para diferentes problemas envolvidos na distribuição federativa, de modo que a redução promovida no texto em análise responde aos propósitos específicos que estão sendo ali investigados. Assim, como se viu antes, o caráter temporário da exploração serve para identificar custos de produção que devem ser internalizados, e não critérios de distribuição de renda. Da mesma forma, a volatilidade alerta para um determinado risco relativo ao emprego desses recursos em certas necessidades públicas (custeio de pessoal, p.ex.).

25 A proposta fica mais compreensível se enquadrada num leque analítico mais amplo, oferecido por Giorgio Brosio no estudo anteriormente citado (Oil revenue and fiscal federalism). Depois de realizar um esforço de "depuração" conceitual em torno do objeto da repartição, semelhante àquele realizado no estudo em análise (p. 252-254), Brosio faz um inventário dos possíveis arranjos distributivos, distinguindo os seguintes: - Tax base sharing, que representa o maior grau de autonomia fiscal para os entes subnacionais. Nesse sistema, são os entes federados que instituem, arrecadam e fiscalizam o recolhimento de ônus específicos incidentes sobre a exploração de recursos naturais em seus territórios; - Tax revenue sharing, arranjo no qual a instituição do ônus fica a cargo do ente central que, porém, tem a obrigação de distribuir o resultado entre os entes subnacionais; - In-kind revenue sharing, no qual os entes subnacionais têm acesso à renda mineral por meio de investimentos em infraestrutura conduzidos diretamente pelas companhias operantes em seus territórios, determinados em conjunto pelo governo/população local e o agente econômico (Ibid, p. 255-257).

26 Brosio e Jimenez, The intergovernmental assignment of revenue from natural resources, op. cit., p. 17-20. 
conquanto teoricamente interessante, parece estar afastada de nosso direito positivo.

Mais próximas de nossa realidade jurídica são as propostas de fundos setoriais. A ideia que os estrutura é simples:

They amount to reserve a share of total national revenue from natural resources to the non producing, or little producing, jurisdictions and to distribute them according, either the distance of their resource revenue from the national average, or to other needs, or revenue capacity related indicators. ${ }^{27}$

Brosio e Jimenez não desenvolvem em detalhes esses mecanismos na parte analítica de seu estudo, mas oferecem exemplos deles na segunda parte, dedicada ao exame de diferentes experiências latino-americanas.

Para encerrar essa breve exposição, sinaliza-se um ponto que mereceria maiores esclarecimentos.

Tendo presente que os autores reconhecem ser necessária a equalização (premissa sub (b), acima), não fica claro se preconizam, a título de policy, alguma equalização ou equalização total.

Isso se diz na medida em que o critério que apontam no início do estudo para orientar tal decisão parece ser mais apto para justificar a imputação dos custos, sendo de pouca ajuda para pautar uma decisão sobre a distribuição da renda:

Essentially, the policy indications stress the consideration that policy-makers have to give, when bargaining over shares, to the effective responsibilities carried out by various levels of government, while arguments of principle or a priori should be given very little weight. ${ }^{28}$

27 Ibid., p. 20.

28 Ibid., p. 6. Compare-se isso com quanto dizem Brosio e Jimenez ao tratar da necessidade de reconhecer como custos os investimentos feitos em razão da responsabilidade de cada agente público: "the cost of infrastructure for providing services to the population that has migrated to a oil field or mine area does not form part of the rent, has to be added to other costs and has to be funded to the level government that has actually provided the services and borne the costs. The relative importance of the costs refunded to the central or to the regional government will depend on the extent of responsibilities assigned to them" (p. 11). 
No momento em que, vencidas (ou mitigadas) as objeções contra a repartição descentralizada das rendas, passam à análise de seus mecanismos de implementação, não há uma tomada de posição explícita quanto a esse ponto. Os autores reconhecem a tensão entre as diferentes forças políticas e descartam a possibilidade de uma alocação geográfica "total", sem, no entanto, esclarecer se o resultado leva à repartição absolutamente isonômica ou diferenciada:

At the same time, the prevalent concentration of these resources in only a few areas produces an overall inequality in the distribution of revenue to subnational governments that modern governments find difficult to accept. Most countries try as a consequence to reduce the disparities in local revenues created by local assignment of natural resources revenues.

No estudo anterior, Brosio parece ter assumido como policy decorrente de princípios de "justiça distributiva" uma equalização parcial que reconhece, mesmo no âmbito da verdadeira renda, uma parcela maior para as regiões produtoras:

On the basis of coutries' current social and redistribution policies, it is hard to imagine a country's social welfare function that would assign the entire oil revenue to producing jurisdictions. At the same time, it would be hard to imagine a social welfare function that would totally disregard the claims of the producing jurisdictions to have a share of net oil rents. In other words, present-day political orientations are for redistribution of wealth, but not to total equalization, which translates into centralized assignment of most net oil rent and recognition of a small share to the producing jurisdictions.

Talvez ajude a reforçar esse entendimento a consideração de um elemento referido por Brosio no estudo anterior, mas não inteiramente desenvolvido por ele.

Ao descrever o fenômeno do boomtown nas regiões hospedeiras, o professor de Turim refere um fator que dificilmente pode ser mensurado do mesmo modo que a demanda por infraestrutura e a compensação pela degradação ambiental. Trata-se da necessidade de promover, pro futuro, a diversificação do crescimento econômico das áreas que recebem a indústria: "Local governments' involvement in controlling damages, providing infrastructure, and 
diversifying growth can hardly be denied, but it requires resources and skills"29 (grifou-se).

Já se falou desse elemento no início desta resenha, ao se referir genericamente a exigências de "justiça intergeracional", envolvidas na distribuição das rendas da indústria do petróleo. Seria o caso de indagar aos professores se tal fator poderia ser considerado (i) um componente a ser relacionado com a renda (e não considerado como custo) e, em caso afirmativo, se poderia ser (ii) um componente que fundamenta uma distribuição regionalmente diferenciada desta renda.

Feita essa observação, quid iuris, relativamente a esta terceira parte?

O equalization claim formulado pelos professores Brosio e Jimenez lança luz sobre uma perspectiva também pouco explorada do art. 20, §1ํㅡㄹ Constituição cuja consideração pode contribuir decisivamente para a compreensão do sentido correto do dispositivo.

Até 1988, apenas o petróleo ensejava receitas para os entes subnacionais hospedeiros (ou adjacentes à plataforma continental).

Essa circunstância foi sentida explicitamente nos debates da Assembleia Nacional Constituinte e o resultado foi uma decisiva ampliação da "base imponível", i.e., das explorações de recursos naturais que ensejariam repartição. O pronunciamento do constituinte Nelson Carneiro dá o tom do pensamento da Assembleia:

Sr. Presidente, Srs. Constituintes, o nobre Constituinte José Serra sustenta que apenas deva ser paga essa participação no que diz respeito a petróleo e gás, e, em numerosos Estados do País não há nem petróleo nem gás. De modo que essa emenda que o Constituinte José Serra defende como substitutiva da que está ora em exame divide o Brasil. Quem tem petróleo e gás poderá ter participação. Quem não tem mas tem outras terras inundadas, problemas de eletricidade como o Paraná, por exemplo, deixa de ter esse direito. A emenda que se vai aprovar, já que essa é a manifestação do Plenário, essa emenda não distingue, incluiu o petróleo e o gás, mas não exclui nenhum outro recurso mineral. Uma emenda para o Brasil e não para os Estados que têm petróleo e gás!

\footnotetext{
${ }^{29}$ Brosio, Oil revenue and fiscal federalism, op. cit., p. 251.
} 
A intenção era, exatamente, de garantir uma forma - uma forma dentre outras, bem entendido - de equalização nacional.

Assim é que se passou do petróleo para a totalidade dos recursos minerais (como o hidrocarboneto, recursos naturais não renováveis), e, ainda, para o aproveitamento do potencial hidráulico para fins de geração de energia elétrica (recurso natural, em certo sentido, renovável).

Se se toma essa ampliação como a providência requerida pela isonomia, compreende-se como natural a adoção do critério geográfico, inclusive para a plataforma continental, ${ }^{30}$ ainda mais quando esta decisão foi tomada sob a proteção do "véu da ignorância" ${ }^{31}$ do pré-sal. A ideia era a de uma partilha federativa "a cada um segundo suas riquezas". ${ }^{32}$

Em síntese, e recolhendo os resultados desse estudo para nossa discussão doméstica:

1) do primeiro ponto desenvolvido pelos autores, resultam duas coisas:

a. em primeiro lugar, uma "organização da casa", relativamente ao objeto em disputa. Ao tratarmos de ratio jurídica, tenhamos presente que os economistas falam de diferentes racionalidades econômicas para diferentes fenômenos: no mínimo deveríamos ter presente a distinção entre ressarcimento de custos e distribuição de renda. O primeiro se mensura e habilita quem nele incorre; a segunda está à disposição de uma luta política e de considerações de outra índole, inclusive relacionadas a exigências de justiça distributiva e intergeracional.

b. Essa distinção, aliás, parece estar sugerida em nossa Constituição, que, no art. 20, §1ํㅡㄹ fala em "compensação financeira" pela exploração dos recursos naturais e de "participação no resultado" dessa mesma exploração. ${ }^{33}$ Não acaso, o Supremo Tribunal Federal, no RE já referido (228.800-DF), vincula a compensação financeira à perda sofrida, ao mesmo tempo que reconhece que, constitucionalmente, é possível

30 Ponto que não depende apenas do texto do dispositivo, como já referido, mas que exige argumentos adicionais que não serão apresentados aqui.

31 Veja Brosio, Oil revenue and fiscal federalism, op. cit., p. 255-256.

32 Veja, a propósito, o meu Participações governamentais na indústria do petróleo, Fabris: Porto Alegre, 2012.

33 Corretamente, nessa direção, vai FERREIRA FILHO, Manuel Gonçalves. Comentários à Constituição brasileira de 1988. São Paulo: Saraiva, 1990, muito antes da disputa nascer: "A norma distingue entre participação e compensação. Esta última pressupõe um 'prejuízo' decorrente da exploração. Já a participação constitui uma associação nos benefícios.// Compreende-se que o ente federativo que no seu território sofra a exploração, seja por ela compensado, ou, até, nela tenha uma participação" (p. 154). 
instituir um ônus econômico sobre a mineração que nada tenha a ver com tal perda. ${ }^{34}$

2) Do segundo ponto, resultam preciosas informações acerca de certos riscos (tendências econômicas) envolvidos na distribuição federativa que, se não podem impedir que se realize (de lege lata, tendo em vista o direito brasileiro), podem orientar o legislador na fixação dos percentuais e, mais do que isso, impeli-lo para criação de mecanismos que mitiguem os riscos apontados (padrões de aplicação das receitas; mecanismos de controle e participação popular etc.).

3) Por fim, quanto ao terceiro ponto, a exigência de atenção à equalização suscita uma interpretação do dispositivo constitucional (art. 20, §1 ${ }^{\circ}$ ) que privilegie, exatamente, a consideração da ampliação da base

34 Este julgado contém muito mais informações do que normalmente se tira dele. Em síntese, por ele a Constituição teria deixado a critério do legislador ordinário instituir (a) uma indenização por (a.1) danos e (a.2) impactos da instauração da atividade mineral no território. Nesse caso, tais circunstâncias seriam a medida da obrigação; ou (b) uma participação no resultado, caso em que não haveria, propriamente, medida ou limite. Imposições ad valorem consubstanciam participações no resultado. Confira-se do voto condutor do min. Sepúlveda Pertence: “Tenho, no entanto, que a obrigação instituída pela L. 7.990/89 não corresponde ao modelo constitucional.// Essa compensação financeira há de ser entendida em seu sentido vulgar de mecanismo destinado a recompor uma perda, sendo, pois, essa perda o pressuposto e a medida da obrigação do explorador.// A que espécie de perda, porém, se refere implicitamente a Constituição?// Não, certamente, à perda dos recursos minerais em favor do explorador, pois, nesse caso, a compensação financeira, para compensá-la efetivamente, deveria corresponder à totalidade dos recursos minerais explorados - o que inviabilizaria a sua exploração econômica privada (...).// A compensação financeira se vincula, a meu ver, não à exploração em si, mas aos problemas que gera.// Com efeito, a exploração dos recursos minerais e de potenciais de energia elétrica é atividade potencialmente geradora de um sem-número de problemas para os entes públicos, especialmente para os municípios onde se situam as minas e as represas. Problemas ambientais - como a remoção da cobertura vegetal do solo, poluição, inundação de extensas áreas, comprometimento da paisagem e que tais -, sociais e econômicos, advindos do crescimento da população e da demanda por serviços públicos.// Além disso, a concessão de uma lavra e a implantação de uma represa inviabilizam o desenvolvimento de atividades produtivas na superfície, privando Estados e Municípios das vantagens delas decorrentes" (fls. 376-377). "Pois bem. Dos recursos despendidos com esses e outros efeitos da exploração é que devem ser compensadas as pessoas referidas no dispositivo.// Se assim é, não se justifica que o valor a ser pago a título de compensação financeira seja fixado em função do faturamento, que nada tem a ver com as perdas a que alude implicitamente o art. $20, \S 1^{\circ}$ da Constituição." (fls. 377; grifou-se). Não considerou, porém, inconstitucional a imposição pois a Constituição estabeleceu outra possibilidade: "Na verdade - na alternativa que lhe confiara a Lei Fundamental - o que a L. 7.990/89 instituiu, ao estabelecer no art. 6o que 'a compensação financeira pela exploração de recursos minerais, para fins de aproveitamento econômico, será de até $3 \%$ sobre o valor do faturamento líquido resultante da venda do produto mineral', não foi verdadeira compensação financeira: foi, sim, genuína 'participação no resultado da exploração', entendido o resultado não como o lucro do explorador, mas como aquilo que resulta da exploração, interpretação que revela o paralelo existente entre a norma do art. 20, $\S 1^{\circ}$ e a do art. 176, $\S 2^{\circ}$ da Constituição (...)" (fls. 377; grifou-se). 
imponível como medida de isonomia federativa, legitimando-se, com isso, pelo menos à época (1988), o critério geográfico presente no dispositivo.

Se este último ponto ajuda a explicar a lógica do art. 20, §1ํㅡㄹ legítima é a questão que surge agora, diante do pré-sal: a decisão constitucional se justifica hoje?

\section{Referências}

BARROSO, Luis Roberto. Federalismo, isonomia e segurança jurídica: inconstitucionalidade das alterações na distribuição de royalties do petróleo. Parecer elaborado para o estado do Rio de Janeiro em 16/6/2010. Disponível em: <wWw.migalhas.com.br/arquivo_artigo/art20100708-01.pdf>.

BROSIO, Giorgio. Oil revenue and fiscal federalism. In: DAVIS, Ossowski Fedelino (Org.). Fiscal policy formulation and implementation in oil-producing countries. Washington: FMI, 2003, p. 243-269.

FERREIRA FILHO, Manuel Gonçalves. Comentários à Constituição brasileira de 1988. São Paulo: Saraiva, 1990.

KERN, Rodrigo Lima. Interpretação do art. 20, §1으, da Constituição Federal - A necessidade de tratamento isonômico entre estados e municípios produtores de petróleo, energia elétrica e recursos minerais. Disponível em: <http://jus.uol.com.br/revista/texto/14639/interpretacao-do-artigo -20-1o-da-constituicao-federal>.

LOUREIRO, Luiz Gustavo Kaercher. Participações governamentais na indústria do petróleo. Fabris: Porto Alegre, 2012.

PIRES, Adilson Rodrigues. Breve ensaio sobre as participações governamentais nas atividades de exploração e extração de petróleo. In: . Aspectos tributários relacionados à indústria do petróleo e gás. Rio de Janeiro: MP Editora, 2011.

POSTALI, Fernando Antônio Slaibe. Renda mineral, divisão de riscos e benefícios governamentais na exploração de petróleo no Brasil. Rio de Janeiro: BNDES, 2002. SERRA, Rodrigo Valente. Contribuições para o debate acerca da repartição dos royalties petrolíferos no Brasil. Tese (doutorado). Disponível em: <www. royaltiesdopetroleo.ucam-campos.br/index.php?cod=4>. 
SILVA, Sandra Maria do Couto; OLIVEIRA, Jorge Rubem Folena, Dos royalties do petróleo: o Princípio Federativo e a competência dos estados para editarem leis sobre sua cobrança e fiscalização. Disponível em: <www.pge.proderj. rj.gov.br/Revista63/0313-DosRoyaltesPetroleo.pdf>.

TORRONTEGUY, Alessandra Fölzke. A aplicação dos royalties do petróleo na efetividade dos direitos fundamentais sociais. São Paulo: LTr, 2011. 